\title{
O Coração
}

\section{Marina Politi Okoshi, Vitalino Dal Pai}

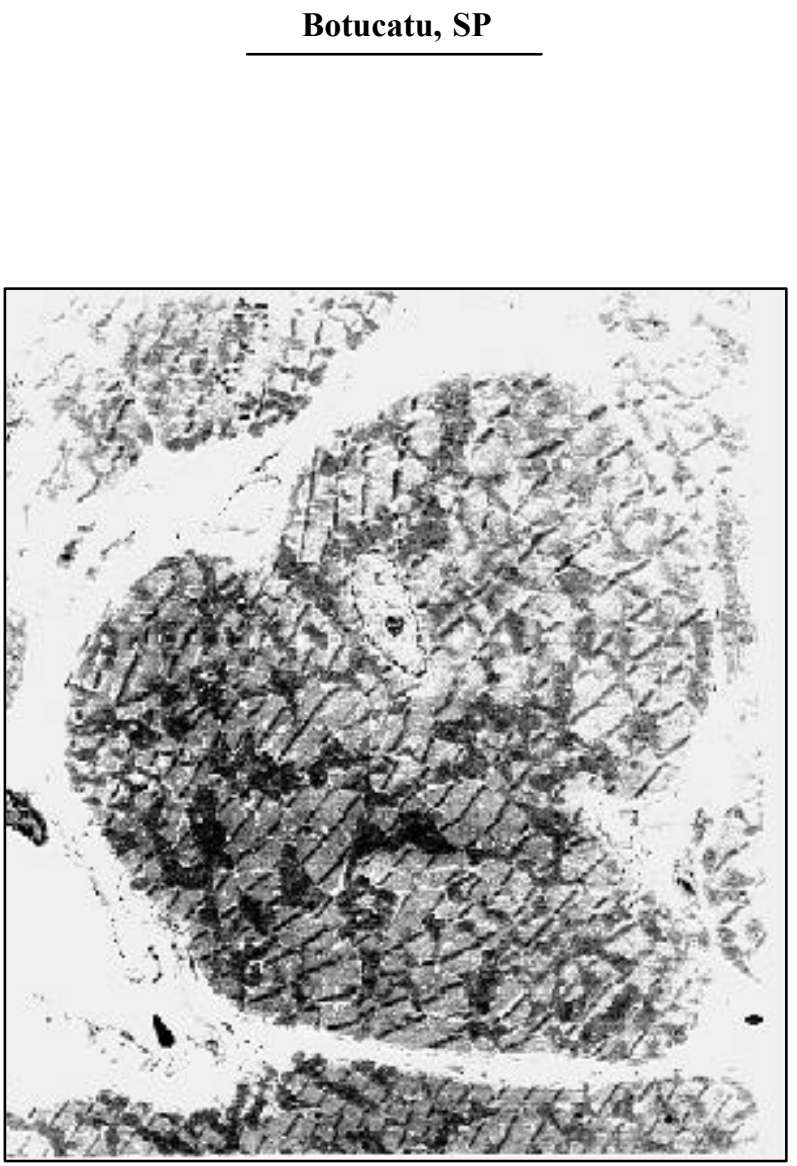

Fig. 1 - Fibra cardíaca do ventrículo esquerdo de rato Wistar-Kyoto (2.750X).

Faculdade de Medicina de Botucatu - UNESP

Correspondência: Marina Politi Okoshi - Faculdade de Medicina de Botucatu-

UNESP - Depto de Clínica Médica - Rubião Júnior, S/N - 18618-000-Botucatu, SP

E-mail: okoshi@cardiol.br - katashi@fmb.unesp.br

Recebido para publicação em 30/10/01

Aceito em 31/10/01 